\title{
Strategi Epidemiologi Dalam Pelayanan Kesehatan Primer
}

\section{The Strategy of Epidemiology In Primary Health Care}

\author{
Buchari Lapau*
}

* Program Studi Magister Ilmu Kesehatan Masyarakat, STIKes Hang Tuah Pekanbaru

\begin{abstract}
Abstrak
Di Indonesia masalah kesehatan termasuk penyakit menular dan penyakit tak menular masih cukup tinggi, yang perlu diatasi dengan pelayanan kesehatan primer yang bermutu, efektif dan efisien. Strategi epidemiologi merupakan lintasan untuk mencapai 3 tujuan epidemiologi. Tujuan makalah ini untuk menunjukkan inovasi bagaimana strategi epidemiologi dapat bermanfaat dalam pelayanan kesehatan primer. Metode: digunakan non-systematic review dan content analysis kepustakaan tentang upaya kesehatan, MDGs (Millineum Development Goals), epidemiologi, pengambilan keputusan berdasar bukti, desentralisasi pelayanan kesehatan, pendidikan tinggi kesehatan masyarakat dan pembiayaan kesehatan. Hasil: Inovasi adalah aplikasi dari ide dan gagasan yang dihasilkan oleh kreativitas yang merupakan suatu proses mental dan proses berpikir. Suatu inovasi menghasilkan jasa-jasa atau cara kerja yang lebih efektif dan efisien. Pengambilan Keputusan Berdasar Bukti (PKBB) merupakan suatu ide, hasil kreativitas dari para ahli berbagai ilmu antara lain Epidemiologi, dengan mana dilakukan analisa data dan informasi. Kegiatan seperti ini tidak sempurna dan sulit dilaksanakan bila hanya dilakukan di tingkat pusat dan tingkat provinsi; karena itu di tingkat kabupaten/kota perlu ada inovasi dengan membentuk Tim Epidemiologi Manajemen Kabupaten (TEMK) dalam rangka meningkatkan mutu manajemen dan mengintensifkan pelayanan kesehatan primer. Namun inovasi ini mengalami hambatan sehubungan dengan kebijakan pemerintah dalam pelayanan kesehatan primer, pendidikan tinggi kesehatan masyarakat, desentralisasi pelayanan kesehatan dan pembiayaan pelayanan kesehatan. Kesimpulan: Perlu dibuat rencana strategis pelayanan kesehatan primer bukan hanya MDGs tetapi secara menyeluruh, evaluasi pendidikan tinggi kesehatan masyarakat, meninjau kembali undang-undang dan peraturan dalam rangka desentralisasi, sedangkan pemerintah eksekutif dan legislatif memberikan perhatian dan komitmen terhadap perkembangan praktek kesehatan masyarakat.
\end{abstract}

\begin{abstract}
In Indonesia, the health problem including communicable and non-communicable diseases has been relatively high, which is necessary to be solved by effective, efficient and high quality of primary health care. The strategy of epidemiology is the road to read the 3 purposes of epidemiology. The objective of this paper is to show the innovation of how epidemiology is useful in primary health care. Methods: there are used non-systematic review and content analysis of literature about health care, MDGs (Millenium Development Goals), evidence based decision making, decentralized health services, high education of public health and health services budget. Results: Innovation is the application of idea produced by creativity namely mental and thinking process. Evidence based decision making is the idea as the result of creativity in various sciences including epidemiology, in which the data and information are analyzed. This activity is not complete and difficult if being implemented only at central and provincial levels. That is why, it is necessary to establish Tim Epidemiologi Manajemen Kabupaten (TEMK) translated in English to be District/Municipality Epidemiology - Managemet Team, which is useful to increase management quality and to increase management quality and to intensify primary health care. However,there has been constraint concerning the governmant policy in primary health care, high education in public health, decentralized health services including budget. Conclusion: It is necessary to develop strategic planning of comprehensive primary health care including $M D G s$, to evaluate high education in public health, while executive and legislative government should pay attention and to make commitment for the development of publich health practice.
\end{abstract}

\section{Pendahuluan}

Di Indonesia sampai saat ini angka kematian neonatal, bayi dan balita berbeda-beda diantara pedesaan dan perkotaan, kaya dan miskin, pendidikan tinggi dan pendidikan rendah, dan diantara provinsi;
Status gizi kurang dan buruk, dan berat badan lahir rendah (BBLR) juga berbeda diantara provinsi (Bachtiar, 2011). Penyakit-penyakit demam berdarah, malaria, ISPA, TB dan penyakit-penyakit menular 
lainnya belum terlihat cenderung menurun yang signifikan. Di samping itu beberapa penyakit tak menular seperti penyakit jantung koroner, diabetes mellitus, beberapa jenis kanker meningkat pula. Sebetulnya kematian dan penyakit-penyakit tersebut dapat dikurangi, apabila pelayanan kesehatan primer yang termasuk dalam Upaya Kesehatan Masyarakat (UKM) berjalan dengan baik.

Dalam Sistem Kesehatan Nasional (Depkes, 2004) tertulis dua upaya kesehatan yaitu Upaya Kesehatan Masyarakat (UKM) dan Upaya Kesehatan Perorangan (UKP). UKM terdiri atas tiga strata yaitu strata pertama, strata kedua dan strata ketiga. UKM strata pertama mempunyai 3 fungsi yaitu:

1. Pusat penggerak pembangunan berwawasan kesehatan

2. Pusat pemberdayaan masyarakat di bidang kesehatan dan

3. Pusat pelayanan kesehatan primer- unit pelayanan kesehatan perifer di puskemas.

Unit pelayanan kesehatan primer yang termasuk dalam UKM strata pertama dan dilaksanakan di tingkat puskesmas sekurang-kurangnya terdiri atas:

1. Pelayanan promotif termasuk promosi kesehatan, kesehatan ibu dan anak dan perbaikan gizi

2. Pelayanan preventif termasuk keluarga berencana, kesehatan lingkungan dan pengendalian penyakit

3. Pelayanan kesehatan kuratif yang hanya mencakup pengobatan sederhana

Pelayanan kesehatan primer yang termasuk dalam UKM strata kedua dapat dijelaskan sebagai berikut: Penanggung jawabnya adalah dinas kesehatan kabupaten/kota yang didukung secara lintas sektor. Fungsinya mencakup fungsi manajerial termasuk perencanaan, pelaksanaan dan pengendalian, serta pengawasan dan bertanggung jawab dalam penyelenggaraan pembangunan kesehatan, dan fungsi teknis yang terdiri atas 7 kegiatan seperti tersebut di atas.

Pelayanan kesehatan primer yang termasuk dalam UKM strata ketiga berada di tingkat pusat sebagai berikut: Di Direktorat Jenderal Bina Kesehatan Masyarakat Departemen Kesehatan dikelola promosi kesehatan, kesehatan ibu dan anak dan perbaikan gizi. Di Badan Koordinasi Keluarga Berencana Nasional (BKKBN) dikelola keluarga berencana. Di Direktorat Jenderal Pengendalian Penyakit dan Penyehatan Lingkungan Departemen Kesehatan dikelola pemberantasan penyakit dan penyehatan lingkungan. Di kantor Menteri Negara Lingkungan Hidup dikelola kesehatan lingkungan dan di Direktorat Jenderal Pelayanan Medik dikelola pengobatan.

Sejak tahun 2000 telah dikumandangkan Millenium Development Goals (MDGs) yang pada tahun 2015 harus dicapai tujuannya (Dit. Jen. Binkesmas, 2010) yaitu:

1. mengentaskan kemiskinan dan kelaparan yang ekstrim

2. pemerataan pendidikan dasar

3. Mendukung adanya persamaan jender dan pemberdayaan perempuan

4. Menurunkan angka kematian anak

5. Meningkatkan kesehatan ibu

6. Memerangi HIV/AIDS, malaria dan penyakit lainnya

7. Menjamin kelestarian lingkungan hidup

8. Mengembangkan kemitraan global untuk pembangunan.

Bila diperhatikan 8 tujuan dari MDGs tersebut, maka tujuan MDGs nomor 4, 5 dan 6 tersebut menyangkut bidang kesehatan. Pelayanan kesehatan primer dalam MDGs adalah gizi, pelayanan kesehatan ibu dan anak, pemberantasan penyakit menular khususnya TB, malaria dan HIV/AIDS, air bersih dan obat esential. Namun kegiatan pelayanan kesehatan primer jangan hanya terarah kepada MDGs yang merupakan program internasional, jangan kita lengah terhadap penyakit-penyakit menular lainnya, penyakit tak menular dan program-program kesehatan lainnya (Gani, 2011). Dengan demikian pencapaian MDGs hanya sebagian dari tujuan yang seharusnya dicapai oleh pelayanan kesehatan primer, walaupun mungkin sebagai prioritas. Tujuan suatu program adalah untuk mengatasi situasi masalah melalui determinant atau faktor-faktor yang berhubungan atau berpengaruh terhadap situasi masalah itu. Dengan demikian untuk mencapai suatu tujuan program pelayanan kesehatan primer termasuk MDGs diperlukan antara lain epidemiologi.

\section{Tujuan:}

Tujuan dari makalah ini adalah menunjukkan inovasi bagaimana strategi epidemiologi dapat bermanfaat dalam pelayanan kesehatan primer.

\section{Metode:}

Dilakukan content analysis (Lapau, 2011) pada kepustakaan yang menyangkut upaya kesehatan, MDGs, epidemiologi, pengambilan keputusan berdasar bukti, desentralisasi pelayanan kesehatan, pendidikan tinggi kesehatan masyarakat dan pembiayaan kesehatan.

\section{Hasil Tinjauan Kepustakaan}

\section{Pengambilan Keputusan Berdasar Bukti}

Inovasi adalah aplikasi dari ide atau gagasan, yang dihasilkan oleh kreativitas yang merupakan suatu proses mental dan proses berpikir. Suatu inovasi 
menghasilkan jasa-jasa atau cara kerja yang lebih efisien (Setiawan, 1985). Pengambilan keputusan berdasar bukti merupakan suatu ide, hasil kreativitas dari para ahli berbagai ilmu antara lain epidemiologi. Aplikasi dari pengambilan keputusan berdasar bukti kepada manajemen pelayanan/program kesehatan merupakan suatu inovasi dalam pelayanan kesehatan.

Epidemiologi adalah ilmu yang bertujuan untuk mendiagnosis masalah kesehatan masyarakat, mengidentifikasi riwayat alamiah dan etiologi penyakit dan memberikan informasi yang dapat digunakan untuk manajemen pelayanan/program kesehatan (Lowe and Kostrzewski, 1973). Untuk tiga tujuan tersebut ada dua strategi epidemiologi yaitu surveilans epidemiologi dan penelitian epidemiologi. Baik surveilans ataupun penelitian epidemiologi adalah kegiatan-kegiatan pengumpulan, pengolahan dan analisa data untuk menghasilkan informasi dan selanjutnya menghasilkan informasi menjadi bukti. Perbedaannya adalah bahwa Surveilans merupakan kegiatan rutin, sedangkan penelitian dilakukan bila tak ada atau jarang informasi dari hasil surveilans (Lapau, 2009).

Pengambilan keputusan berdasar bukti merupakan suatu pendekatan ilmiah khususnya epidemiologi (Gray, 2001) yang diterapkan dalam manajemen pelayanan kesehatan sebagai suatu inovasi. Dalam hal ini dilakukan pendekatan sistem dalam pelayanan/program kesehatan sebagai berikut:

\section{Input $\rightarrow$ Proses $\rightarrow$ Output $\rightarrow$ Efek $\rightarrow$ Dampak}

Input adalah sumber daya (tenaga manusia, fasilitas/logistik dan uang untuk pembiayaan) yang diperlukan supaya proses (kegiatan) sistem dapat berjalan sehingga secara langsung dapat dihasilkan output yang segera dapat diukur. Efek adalah perilaku masyarakat yang dapat menerima atau menolak pelayanan/program kesehatan dan dampak menggambarkan status kesehatan masyarakat yang diukur dengan angka kematian, angka penyakit dan/atau angka kecacatan. Bila masyarakat menolak sistem pelayanan/program, maka target output mungkin tak tercapai. Bila masyarakat menerimanya, maka output dapat tercapai dan dampak mungkin membaik.

Seperti tersebut di atas strategi epidemiologi yaitu baik surveilans atau penelitian epidemiologi mempunyai kegiatan-kegiatan pengumpulan, pengolahan dan analisa data sehingga dihasilkan informasi. Bila ingin informasi dijadikan bukti, diperlukan 4 kegiatan yaitu relevansi, koherensi, konteks populasi, geografi dan siklus manajemen. Relevansi menjawab pertanyaan apakah indikator- indikator dalam output, proses, input, efek dan dampak berhubungan satu sama lain. Koherensi menjawab pertanyaan apakah hubungan tersebut selalu terjadi menurut waktu dan tempat. Konteks populasi dan geografis menjawab pertanyaan apakah informasi yang dihasilkan berguna untuk kelompok penduduk dan geografi tertentu. Siklus manajemen menjawab pertanyaan apakah informasi yang dihasilkan berguna untuk melakukan perencanaan, pemantauan dan penilaian.

Salah satu data input di tingkat nasional pada 3 propinsi di Indonesia yaitu di Propinsi NTT, Bali dan Lampung, menunjukkan bahwa pembiayaan program upaya kesehatan masyarakat berkisar antara 2,9\% sampai $12 \%$, sedangkan biaya untuk program upaya kesehatan perorangan berkisar antara 32,1\% sampai $66,6 \%$, lalu biaya pembangunan kapasitas penunjang berkisar antara $28,8 \%$ sampai $55,7 \%$. Jelas terlihat pembiayaan terhadap pelayanan kesehatan primer dalam arti preventif dan promotif jauh lebih kurang dari pada pelayanan kuratif. Pengalaman di Denmark yang menangani salmonellosis dengan usaha penyelidikan ke arah preventif jauh lebih murah dari pada pengalaman di Amerika Serikat yang menangani salmonellosis dengan hanya cara kuratif (Gani, 2010).

Pengambilan Keputusan Berdasar Bukti (PKBB) dalam manajemen pelayanan/program kesehatan sulit dilakukan secara nasional atas dasar data dan informasi dari kabupaten dan provinsi, Karena itu PKBB perlu dilakukan pada tingkat dinas kesehatan kabupaten/kota, puskesmas dan rumah sakit. PKBB pada tingkat kabupaten bertujuan untuk:

1. mengintensifkan pelaksanaan program-program kesehatan,

2. meningkatkan manajemen kesehatan

3. melakukan kemitraan untuk keberhasilan butir satu dan butir dua

Dalam rangka butir satu diperlukan subdisiplin surveilans epidemiologi dan penelitian operasional, sedangkan dalam rangka butir dua diperlukan subdisiplin manajemen strategi dan manajemen mutu/audit. Untuk mencapai tiga tujuan tersebut di atas, maka di tingkat dinas kesehatan kabupaten/kota perlu dibentuk Tim Epidemiologi Manajemen Kabupaten (TEMK) yang berfungsi sebagai berikut:

1. memberikan keterampilan kepada staf dinas kesehatan kabupaten, puskesmas dan rumah sakit untuk merencanakan dan melaksanakan surveilans epidemiologi dan pelaksanaan penelitian operasional

2. mengkoordinir kegiatan interpretasi informasi menjadi bukti yang dapat digunakan oleh kepala 
dinkes kabupaten/ kota untuk pengambilan keputusan dalam rangka menyusun perencanaan strategis dan operasional yang diadvokasikan ke BAPPEDA, DPRD dan lintas sektor

3. membantu kepala dinas kesehatan kabupaten untuk melakukan pemantauan dan penilaian progamprogram kesehatan

Di tingkat puskesmas dibentuk pula Tim Epidemiologi Manajemen Puskesmas (TEMPus) yang berfungsi untuk melakukan interpretasi informasi menjadi bukti dalam rangka pengambilan keputusan oleh kepala puskesmas untuk melakukan perencanaan, pemantauan dan penilaian pelayanan/program kesehatan. Sampai saat ini boleh dikatakan hampir seluruh dinas kesehatan kabupaten/kota dan puskesmas belum mempunyai TEMK dan TEMPus. Untuk mengisi posisi dalam TEMK diperlukan tenaga dengan kualifikasi magister kesehatan masyarakat peminatan epidemiologi manajemen dan untuk TEMPus diperlukan sarjana kesehatan masyarakat peminatan epidemiologi.

Pada saat ini di Indonesia sudah berdiri sekitar 150 sampai 160 program studi sarjana kesmas yang belum mempunyai peminatan epidemiologi manajemen dan kurang dari 10 program studi magister kesehatan masyarakat yang hanya 2 dengan peminatan epidemiologi manajemen. Walaupun sudah terlalu banyak program studi kesmas berdiri, dengan adanya kebijakan desentralisasi, pimpinan daerah yang berkuasa seenaknya mengangkat pejabat dalam instansi kesehatan yang bukan berasal dari orang dengan berkualifikasi dalam bidang kesehatan.

\section{Kesimpulan:}

1. Masalah kesehatan yang seharusnya dapat ditanggulangi dengan pelayanan kesehatan primer belum menunjukkan kecenderungan menurun.

2. Kebijakan pemerintah dalam merencanakan pelayanan kesehatan primer seakan-akan tergantung pada dorongan internasional saja, belum menggunakan epidemiologi dalam rangka pengambilan keputusan yang diintegrasikan dengan ilmu yang terkait dengan manajemen dan komunikasi/advokasi untuk mengatasi masalah kesehatan

3. Walaupun sudah banyak berdiri fakultas dan sekolah tinggi yang berkaitan dengan kesehatan masyarakat, kemampuan lulusannya belum berorientasi kepada pengambilan keputusan berdasar bukti, sehingga penentuan kebijaksanaan dan manajemen pelayanan kesehatan tak dapat mengatasi penyakit-penyakit yang seharusnya dapat diatasi dengan pelayanan kesehatan primer

4. Dengan adanya kebijaksanaan desentralisasi pelayanan kesehatan, pemerintah daerah mempunyai kekuasaan segala-galanya termasuk mengangkat pejabat kesehatan yang tak mempunyai keahlian kesehatan, yang tak mengerti pelayanan kesehatan preventif dan promotif sehingga pelayanan kesehatan primer terabaikan.

5. Perhatian dan komitmen pemerintah terhadap pelayanan kesehatan primer belum optimal. Ini terlihat pada sedikitnya pembiayaan untuk pelayanan kesehatan primer dan pendidikan kesehatan masyarakat.

\section{Saran:}

1. Supaya dibuat rencana straregis pelayanan kesehatan primer termasuk pelayanan kesehatan yang termasuk dalam MDGs sebagai prioritas mulai dari tingkat pusat, provinsi dan kabupaten/kota, untuk mana diperlukan tenaga kesehatan yang dapat memanfaatkan epidemiologi dan ilmu yang berkaitan dengan manajemen dan advokasi serta ilmu-ilmu substantif yang relevan, sehingga dapat dihasilkan pengambilan keputusan berdasar bukti, yang selanjutnya dapat mengarahkan advokasi dan manajemen pelayanan kesehatan primer yang efisien dan efektif

2. Dilakukan evaluasi terhadap kurikulum lembagalembaga pendidikan yang melaksanakan pembelajaran kesehatan masyarakat yang bertujuan mendapatkan informasi dalam rangka menyusun kurikulum berbasis kompetensi sehingga lulusannya mempunyai kemampuan teknis yang relevan dan dapat bekerja sama dalam tim untuk meningkatkan pelayanan kesehatan primer atas dasar pengambilan keputusan berdasar bukti

3. Pemerintah eksekutif dan legislatif meninjau kembali undang-undang atau peraturan-peraturan yang sudah ada yang menyangkut kekuasaan pemerintah daerah yang kalau perlu melaksanakan koreksi sehingga jabatan kesehatan dapat diisi oleh sarjana yang mempunyai keahlian kesehatan yang relevan sehingga mampu dalam melaksanakan manajemen pelayanan kesehatan bermutu, efektif dan efisien

4. Pemerintah eksekutif dan legislatif perlu memberikan perhatian dan komitmen terhadap perkembangan ilmu kesehatan masyarakat agar berguna dalam pelayanan kesehatan primer dalam bentuk pembuatan undang-undang atau peraturanperaturan yang menguntungkan pendidikan dan selanjutnya pelayanan kesehatan masyarakat. 


\section{Daftar Pustaka}

Bachtiar, Adang. Isyu Terkini Kesehatan Masyarakat, disajikan pada Seminar Reformasi Pelayanan Kesehatan, yang diadakan STIKes Hang Tuah Pekanbaru tanggal 9 April 2011

Depkes RI. (2004). Sistem Kesehatan Nasional, Jakarta: Depkes RI

Dit. Jen. Binkesmas. Bantuan Operasional Kesehatan (BOK) dan Penerapannya, disajikan pada TOT Studi Operasional BOK di Cikarang tanggal 27 Juli 2010

Gani, Ascobat. Reformasi Pembiayaan Kesehatan, makalah yang disajikan pada Seminar Reformasi
Pelayanan Kesehatan yang diadakan STIKes Hang Tuah Pekanbaru tanggal 9 April 2011

Lapau, Buchari. (2009). Prinsip dan Metode Epidemiologi. Jakarta: Badan Penerbit FKUI

Lapau, Buchari. (2011). Metode Penelitian Kesehatan, satu buku pembelajaran di STIKes Hang Tuah Pekanbaru tahun

Lowe, CR and Kostrzewski. Epidemiology, a guide to teaching method, London: International Epidemiology Association, 1973

Setiawan, Boenyamin. (1985) Peranan Kreativitas dan Inovasi dalam Penelitian, Metodologi Penelitian Bidang Kedokteran, Cetakan Kedua, Editor: Aryatmo, Cokronegoro dkk, Jakarta: FKUI 
